\title{
Cognitive fragility - predictive factor for neurocognitive disorders. Methods of evaluation and prevention of cognitive fragility in clinical practice
}

\section{Fragilitatea cognitivă -factor predictiv pentru tulburările neurocognitive.} Metode de evaluare şi prevenire a fragilităţii cognitive în practica clinică

Oana Maria STANCIU ${ }^{1}$, Cristian TEODORESCU ${ }^{2}$, Sorin RIGA ${ }^{1,3,4}$, Magdalena BUDIŞTEANU ${ }^{3}$, Bogdan BUDIŞTEANU ${ }^{3}$, Dan RIGA ${ }^{1,3,4}$

${ }^{1}$ Universitatea de Medicină şi Farmacie „Carol Davila“, Bucureşti, România ${ }^{2}$ Institutul Naţional de Neurologie şi Boli Neurovasculare, Bucureşti, România ${ }^{3}$ Spitalul Clinic de Psihiatrie „Alexandu Obregia“, Bucureşti, România

${ }^{4}$ Academia Oamenilor de Ştiinţă din România

$\left.\begin{array}{l}\text { ABSTRACT } \\ \text { Frailty is a clinical condition, associated with the pathological aging process, as well as a major risk for the } \\ \text { occurrence of chronic non-communicable diseases (NCDs). Cognitive functions of people over } 65 \text { years old } \\ \text { are influenced by numerous biological, psychological and social factors that contribute to the development of } \\ \text { neurodegenerative disorder. Cognitive decline plays a fundamental role and contributes to the frailty syn- } \\ \text { drome in elderly people, which has led to the emergence of a new concept - cognitive frailty. Unlike most } \\ \text { neurodegenerative diseases, frailty can be partially reversible, with the help of influencing factors and spe- } \\ \text { cific interventions at the emergence of it. }\end{array}\right]$

Keywords: cognitive frailty, elderly, ageing, cognitive impairment

REZUMAT
Fragilitatea este o condiție clinică, asociată cu procesul de îmbătrânire patologică, şi reprezintă un risc
major în apariția afecțiunilor cronice netransmisibile. În cazul persoanelor cu vârsta peste 65 de ani, funcția
cognitivă este influențată de numeroşi factori biologici, psihologici şi sociali care contribuie la dezvoltarea
afecțiunilor neurodegenerative. Declinul cognitiv joacă un rol fundamental în sindromul de fragilitate la
vârstnici, ceea ce a determinat apariția unui nou concept -fragilitatea cognitivă. Cu ajutorul unor interven-
ții specifice în procesul de apariție şi a factorilor infuențabili, fragilitatea, spre deosebire de majoritatea boli-
lor neurodegenerative, poate fi parțial reversibilă.

Cuvinte cheie: fragilitate cognitivă, vârstnic, îmbătrânire, deficit cognitiv 


\section{INTRODUCERE}

Îmbătrânirea este asociată cu prezenţa fragilităţii și a afeç̧iunilor cronice, ceea ce determină o diminuare a răspunsului general de adaptare la stres al organismului, apariţia unui declin funcţional și cognitiv, precum și scăderea autonomiei. Fragilitatea reprezintă o condiţie clinică cu un risc crescut pentru apariţia problemelor de sănătate la pacienţii vârstnici, cum ar fi căderi, dizabilitate, spitalizare și mortalitate (1). Mecanismul etiopatogenic în îmbătrânire este reprezentat de tetrada entropică caracterizată prin stres, uzură, îmbătrânire și polipatologie (2). Astfel, se observă o scădere progresivă a capacităţii adaptative, rezistenţei și vitalităţii. Fragilitatea este o stare intermediară cu rol important în procesul de îmbătrânire și este considerată principalul indicator al îmbătrânirii biologice și al ratei de supravieţuire (3).

Abordarea multidimensională a sindromului de fragilitate a condus la apariţia fragilităţii cognitive. Aceasta implică reducerea flexibilităţii cognitive, creșterea vulnerabilităţii și scăderea adaptabilităţii la stimuli (4).

Termenul de fragilitate cognitivă a fost utilizat pentru prima dată de către Panza și colaboratorii (2006) și definește fragilitatea cognitivă ca fiind o stare particulară de vulnerabilitate cognitivă în tulburarea cognitivă ușoară sau alte afecţiuni care implică prezenţa factorilor de risc cardiovasculari, cu evoluţia ulterioară la stadiul de demenţă (5). Academia Internaţională de Nutriţie și Îmbătrânire (IANA) și Asociaţia Internatională de Geriatrie și Gerontologie (IAGG) au stabilit un consens în ceea ce privește definiţia fragilităţii cognitive. Astfel, criteriul de diagnostic pentru această condiţie clinică asociată cu îmbătrânirea include prezenţa simultană a fragilităţii fizice prin existenţa a cel puţin 3 dintre cele 5 criterii fenotipice (slăbiciune, epuizare autoraportată, activitate fizică redusă, pierderea în greutate neintenţionată, reducerea vitezei de mers), afectarea cognitivă diagnosticată în urma evaluării cu ajutorul scalei Clinical Dementia Rating și excluderea diagnosticului de boală Alzheimer sau alte tipuri de demenţă (6).

\section{DETERIORAREA ŞI REDUCEREA FLEXIBILITĂȚII COGNITIVE LA VÂRSTNICI}

Nivelul de educaţie și capacitatea cognitivă a fiecărui individ determină apariţia unei funcţii cognitive individuale. Procesele cognitive sunt influenţate de capacitatea de adaptare a structurii și a funç̧iei cerebrale, în prezenţa unei patologii sau altor factori care pot afecta capacitatea funç̧iei cerebrale. Factorii de risc și factorii etio-patogenici provoacă și accelerează distresul, deteriorarea, senescenţa patologică, cu apariţia polipatologiei (7). Vârsta reprezintă principalul factor neinfluenţabil care produce modificări de structură și de funcţie la nivelul creierului (8). Anumite procese cognitive, cum este vocabularul, pot prezenta un nivel de dezvoltare și se pot îmbunătăţi odată cu vârsta. Alte procese, precum judecata, raţionamentul și memoria, prezintă un declin pe măsura înaintării în vârstă (9).

Flexibilitatea cognitivă se referă la abilitatea de a schimba modul de gândire (cogniţie) ca urmare a adaptării la cerinţele unui stimul, generând răspunsuri comportamentale adecvate. Declinul cognitiv este variabil și diferă de la o persoană la alta. Fragilitatea poate reprezenta principalul factor care determină această variabilitate (10).

\section{POATE FI REVERSIBILĂ FRAGILITATEA COGNITIVĂ?}

Un număr tot mai mare de studii epidemiologice sugerează că fragilitatea poate crește riscul de apariţie a declinului cognitiv și, de asemenea, tulburarea cognitivă crește riscul de fragilitate. Astfel, tulburarea cognitivă și fragilitatea pot avea o contribuţie în procesul de îmbătrânire accelerată (11). În încercarea de a îmbunătăţi definiţia fragilităţii cognitive și de a determina potenţialele mecanisme, au fost sugerate două tipuri subclinice: fragilitatea cognitivă „potenţial reversibilă“ și fragilitatea cognitivă „reversibilă“ (12). Potenţialul de reversibilitate a fragilităţii poate fi un obiectiv secundar în prevenirea dependenţei și a altor efecte negative la pacienţii vârstnici (13).

\section{METODE DE SCREENING ŞI INSTRUMENTE DE DIAGNOSTIC}

În timp ce factorii fizici ai fragilităţii cognitive au fost identificaţi cu ajutorul fenotipului de fragilitate Fried, componenta cognitivă nu este pe deplin stabilită. Studiile publicate până în prezent au utilizat diferite instrumente operaţionale ale fragilităţii cognitive, în timp ce fragilitatea fizică a fost diagnosticată cu ajutorul criteriilor de fenotip (14). Grupul de lucru Internaţional (IANA/IAGG), care a elaborat definiţia fragilităţii cognitive, propune ca toţi pacienţii fragili să fie evaluaţi cu ajutorul unor teste de evaluare cognitivă cuprinzătoare (Comprehensive Cognitive Assessments). Evaluarea funcţiei cognitive la vârstnic, în vederea identificării fragilităţii cognitive, poate fi realizată cu ajuto- 
rul testului Montreal Cognitive Assessment (MOCA), Mini-Mental State Examination (MMSE) și testul vitezei de mers $(6,15)$.

S-a observat o afectare mai severă a funcţiilor executive în cazul pacienţilor cu fragilitate cognitivă comparativ cu persoanele cu deficit cognitiv, dar care nu asociază și fragilitate. Capacitatea de procesare a informaţiilor, atenţia selectivă, flexibilitatea cognitivă sunt principalele funcţii executive diminuate și care determină o afectare cognitivă subcorticofrontală (16).

\section{BIOMARKERI ÎN EVALUAREA FRAGILITĂȚII COGNITIVE}

Posibilii biomarkeri comuni care pot sugera atât riscul unui declin fizic, cât și al unui declin cognitiv sunt markerii inflamatori - proteina $\mathrm{C}$ reactivă și interleukina-6. Cu toate acestea, cei doi markeri biologici nu sunt deosebit de utili în ceea ce privește diferenţierea declinului fizic de cel cognitiv $(8,17)$.

Stabilirea riscului pentru declinul cognitiv poate fi efectuat $\mathrm{cu}$ ajutorul markerilor specifici acumulării de $\beta$-amiloid și apolipoproteina $E$ - genotipare (18). Deteriorarea cognitivă reversibilă ar putea fi premegătoare unei tulburări cognitive ușoare, care poate fi o formă preclinică a bolii Alzheimer sau a altor tipuri de demenţă. Deteriorarea cognitivă posibil reversibilă ar putea corespunde tulburării cognitive ușoare și a unui stadiu predemenţă (19). Pacienţii cu fragilitate cognitivă reversibilă la care a fost infirmată prezenţa bolii Alzheimer cu ajutorul biomarkerilor specifici pot $\mathrm{fi}$ indivizi cu îmbătrânire cognitivă normală sau cu un stadiu al bolii Alzheimer neidentificat (20).

\section{FACTORII DE RISC CARDIOVASCULARI ŞI FRAGILITATEA COGNITIVĂ}

În prezent, hipertensiunea arterială, insuficienţa cardiacă, boala cardiacă ischemică, boala arterială periferică, diabetul zaharat au fost asociate cu fragilitatea și tulburările cognitive. În ceea ce privește fragilitatea cognitivă, nu s-a stabilit o asociere între aceasta și factorii de risc cardiovasculari. Atât fragilitatea, cât și afeç̧iunile cardiovasculare, au o componentă comună - inflamaţia (21). Identificarea precoce a rigidităţii arteriale reprezintă o ţintă importantă în prevenţia aterosclerozei și o strategie terapeutică pentru ameliorarea prognosticului afecţiunilor cardiovasculare (22).

Fragilitatea fizică poate preceda apariţia unei demenţe vasculare din cauza prezenţei unor leziuni ischemice la nivelul creierului și a modificări valorilor unor biomarkeri vasculari (23). De asemenea, principalele dovezi imagistice care asocia- ză fragilitatea cu declinul cognitiv sunt reprezentate de prezenţa leucoaraiozei (24). Identificarea precoce a deficitului cognitiv și reducerea factorilor cardiovasculari pot ameliora sindromul de fragilitate la vârstnici, îmbunătăţind astfel calitatea vieţii acestora (25).

\section{SARCOPENIA}

Sarcopenia este cea mai recunoscută și reprezentativă componentă clinică a fragilităţii. Sarcopenia se referă la pierderea involuntară a masei musculare scheletice și a forţei musculare, pierdere asociată cu îmbătrânirea (26). Este, probabil, cea mai studiată componentă a fragilităţii. Din cauza efectelor negative asupra gradului de autonomie a personelor vârstnice, sarcopenia a devenit o reală problemă de sănătate, în special pentru femei, a căror speranţă de viaţă este mai mare decât a bărbaţilor. Aceasta poate fi accelerată în prezenţa comorbidităţilor, cum ar fi insuficienţa cardiacă congestivă, boala arterială periferică (27).

Rezultatele unor studii au evidenţiat o posibilă legătură între prezenţa sarcopeniei și declinul cognitiv (28). Astfel, sarcopenia poate contribui la la un prognostic nefavorabil atunci când este asociată cu boala Alzheimer. Deoarece este un biomarker important al fragilităţii fizice, sarcopenia ar putea fi și un factor predictiv al declinului cognitiv precoce (29).

\section{MĂSURI DE INTERVENȚIE NON- FARMACOLOGICE ÎN PREVENȚIA FRAGILITĂȚII COGNITIVE}

În cazul segmentului de populaţie cu vârsta peste 65 de ani, sunt necesare măsuri de intervenţie în scop preventiv pentru întârzierea apariţiei fragilităţii cognitive. Acestea includ efectuarea activităţilor fizice în mod regulat, o dietă echilibrată, renunţarea la fumat, menţinerea unei greutăţi corporale adecvate, controlul factorilor de risc metabolici și vasculari (30). Fragilitatea fizică și fragilitatea cognitivă reprezintă două fenotipuri de fragilitate care, asociate stadiului de predemenţă, devin ţinta măsurilor de prevenţie secundară (31).

Exerciţiile fizice și nutriţia reprezintă principala metodă de intervenţie în prevenirea și managementul fragilităţii. Activitatea fizică poate diminua frecvenţa episoadelor de cădere și poate îmbunătăţi capacitatea de mers (32). Alegerea unei diete care să îndeplinească nevoile nutriţionale ale vârstnicului ar putea amâna fragilitatea. Dieta mediteraneeană prezintă un potenţial efect pozitiv 
asupra fragilităţii fizice si cognitive (33). Alte măsuri - cum ar fi tratamentul afecţiunilor cronice, prevenirea căderilor, activitatea fizică care contribuie la menţinerea statusului fizic, nutriţional, cognitiv și psihologic - pot întârzia progresia tulburărilor neurocognitive și, implicit, a dizabilităţii, spitalizării și a ratei de mortalitate.

Datele publicate recent sugerează că activitatea fizică, asociată cu administrarea de proteine, ar putea îmbunătăţi deficitul cognitiv din statusul fragil și pre-fragil, cu impact major în prevenirea declinului cognitiv și funcţional al acestor pacienţi (34).

\section{CONCLUZII}

Prin colaborarea tuturor specialiștilor din domeniile medicale implicate în patologia vârstnicului, ar putea fi elaborate strategii individualizate de prevenţie a fragilităţii cognitive. Recomandările privind utilizarea markerilor clinici, biologici și imagistici pentru această categorie de pacienţi pot contribui la o mai bună înţelegere a acestei condiţii medicale, la prevenirea tulburărilor neurocognitive și la dezvoltarea unor intervenţii specifice care să îmbunătățească gradul de fragilitate și, implicit, să întârzie dizabilitatea.

\section{BIBLIOGRAFIE}

1. Sternberg SA, Wershof Schwartz A et al. The identification of frailty: A systematic literature review. J Am Geriatr Soc. 2011:59:2129-38.

2. Riga $D$, Riga $S$. Medicina Antiîmbătrânire şi ştiinţele longevităţii. Bucureşti: Editura Cartea Universitară, 2007:99-118.

3. Morley JE, Vellas B, van Kan GA et al. Frailty consensus: A call to action. JJ Am Med Dir Assoc. 2013 Jun;14(6):392-7.

4. Yu R, Morley JE, Kwok T. The effects of combinations of cognitive impairment and pre-frailty on advers outcomes from a prospective community-based chorot study of older chinese people. Front Med. 2018:6:5:50.

5. Panza F, D'Introno A, Colacicco AM et al Cognitive frailty: Predementia syndrome and vascular risk factors. Neurobiol Aging. 2006;27(7):933-40.

6. Kelaiditi E, Cesari M, Canevelli M et al. Cognitive frailty: Rational and definition from an (I.A.N.A.II.A.G.G.) international consensus group. J Nutr Health Aging. 2013;17(9):726-34.

7. Riga S, Riga D. Stresologie, Adaptologie şi Sănătate Mintală. Bucureşti: Editura Cartea Universitară, 2008:165-178.

8. Harada CN, Natelson Love MC et al. Normal cognitive aging. Clin Geriatr Med. 2013;29(4):737-52.

9. Salthouse TA. Selective review of cognitive aging. J Int Neuropsychol Soc. 2010 16(5):754-60

10. Machado de Jesus It, Sousa Orlando F, Zazzetta MS. Dement Neuropsychol. 2018; 12(2):173-180.

11. Panza F, Solfrizzi V, Frisardi V et al. Different models of frailty in predementia and dementia syndromes. $A$. J Nutr Health Aging. 2011;15(8):711-9.

12. Solfrizzi V, Scafato $E$, Seripa D, et al. Reversible cognitive frailty, dementia, and all-cause mortality. The Italian longitudinal study on aging. J Am Med Dir Assoc. 2017; 18(1):89.e1-89.e8.

13. Panza F, Lozupone $M$, Solfrizzi $V$ et al. Cognitive frailty: a potential target for secondary prevention of dementia. Ageing Res Rev. 2015;20:1-10.
Conflict of interest: none declared Financial support: none declared
14. Fried LP, Tangen CM, Walston J et al. Frailty in older adults: evidence for a phenotype. Cardiovascular Health Study Collaborative Research Group. J Gerontol A Biol Sci Med Sci. 2001;56(3):M146-56.

15. Valkanova V, Esser P, Demnitz N Association between gait and cognition in an elderly population based sample. Gait Posture. 2018;65:240-245.

16. Delrieu J, Andrieu S, Pahor M et al. Neuropsychological profile of "cognitive frailty" subjects in MAPT Study. J Prev Alzheimers Dis. 2016;3:151.

17. Wallace $\mathrm{L}$, Theou O, Rockwood K et al. Relationship between frailty and Alzheimer's disease biomarkers. A scoping review. Alzheimers Dement. 2018; 10:394-401.

18. Panza F, Seripa D, Solfrizzi V et al. Targeting cognitive frailty: Clinical and neurobiological roadmap for a single complex phenotype. J Alzheimers Dis. 2015; 47:793-813

19. Ruan Q, D'Onofrio G, Sancarlo D et al. Emerging biomarkers and screening for cognitive frailty. Aging Clin Exp Res. 2017; 29(6):1075-1086.

20. Ruan Q, D'Onofrio G, Sancarlo D et al. Potential fluid biomarkers for pathological brain changes in Alzheimer's disease: Implication for the screening of cognitive frailty. Mol. Med. Rep. 2016; 14(4):31843198.

21. Stanciu OM, Riga D, Aurelian SM et al. Abst. In: Inflammation and cardiovascular risk in fragile syndrome diagnosis. Preliminary data. Rom. Med. Rev. 2017; LXIV:Suppl:116-117.

22. Aurelian SM, Stanciu OM, Zamfirescu A et al. Diabetes Mellitus as Cardiovascular Disease. Bucharest: Editure Niculescu, 2016:79-88.

23. Newman AB, Gottdiener JS, Mcburnie MA et al. Associations of subclinical cardiovascular disease with frailty. Cardiovascular Health Study Research Group. J Gerontol A Biol Sci Med Sci. 2001; 56(3):M158-66.

24. Schmidt R, Petrovic K, Ropele S et al. Progression of leukoaraiosis and cognition. Stroke. 2007;38:2619-2625
25. Burkauskas J, Lang P, Bunevicius A. Cognitive function in patients with coronary artery disease: A literature review. $J$ Int Med Res. 2018;46(10):4019-4031.

26. Cruz-Jentoft AJ, Baeyens JP, Bauer J et al. Sarcopenia: European consensus on definition and diagnosis. Report of the European Working Group on Sarcopenia in Older People. Age Ageing. 2010; 39(4):412-423.

27. Buford TW, Anton SD, Judge AR et al. Models of accelerated sarcopenia: critical pieces for solving the puzzle of age-related muscle atrophy. Ageing Res Rev. 2010; 9(4):369-83.

28. Van Dam R, Van Ancum JM, Verlaan S et al. Lower cognitive function in older patients with lower muscle strength and muscle mass. Dement Geriatr Cogn Disord. 2018; 45:243-250.

29. Shimada H, Doi T, Lee S et al. Cognitive frailty predicts incident dementia among community-dwelling older people. J Clin Med. 2018;7(9):250.

30. Puts MTE, Toubasi S, Andrew MK et al. Interventions to prevent or reduce the level of frailty in community dweling older adults: a scoping review of the literature and international policies. Age Ageing. 2017; 46(3):383-392

31. Lim W-S, Canevelli M, Cesari M. Editorial: Dementia, frailty and aging. Front Med (Lausanne). 2018;5:168.

32. Theou O, Stathokostas L, Roland KP et al. The effectiveness of exercise interventions for the management of frailty: a systematic review. J Aging Res. 2011:569194.

33. Dominguez LJ, Barbagallo $M$. The relevance of nutrition for the concept of cognitive frailty. Curr Opin Clin Nutr Metab Care. 2017:20:61-68.

34. Van de Rest O, Van der Zwaluw NL, Tieland $\mathrm{M}$ and al. Effect of resistance-type exercise training with or without protein supplementation on cognitive functioning in frail and pre-frail elderly: secondary analysis of a randomized, double-blind, placebo-controlled trial. Mech Ageing Dev. 2014;136-137:85-93. 